\title{
A HISTORY OF THE SOUTH AFRICAN DEFENCE FORCE INSTITUTE (SADFI) 1916 - $1991^{\$}$
}

Capt I.J. van der Waag *

On 1 January 1916, the Union Defence Force assumed control of the South West African branches of the South African Garrison Institutes (SAGI) and five months later, the branches at Potchefstroom and in the Cape Peninsula. Now in 1991, it is an apt time to reflect upon the 75 years of service provided by the South African Defence Force Institute (SADFI), to the South African Defence Force and its predecessor.

\section{Introduction}

For centuries the well-being of the soldier was no particular organization's official concern. Despite the changes brought by the military revolution during the seventeenth century, little to nothing was done to improve the living conditions of combatant soldiers and provide troops on the front-line with everyday comforts, refreshments and small luxuries.

For the greater part, soldiers were left to plunder food and clothes from the civilian population. This was particularly the case of armies moving through a foreign country. Anything they wanted was simply seized as part of the spoils of war. Occasionally troops even pillaged their home country, as the South Fencibles did when stationed at the West Barns camp near Dunbar at the end of the eighteenth century. On this occasion the situation was so bad, that the commander of the troops on the east coast of Scotland, Henry 3rd Duke of Buccleuch, had to publish orders prohibiting "all plundering, marauding, cutting down trees, killing and destroying game'.1

Despite the fact that civilians normally bore the brunt of exploitation during warfare, in many cases the soldiers, themselves, were the victims. Traditionally, small traders known as sutlers would follow armies during a military campaign. During the march, prices would be reasonable and fairly competitive with the markets in local towns. However, as soon as the battle started, the sutlers would push up their prices, with the knowledge that the soldier on the frontline had no choice but to buy from him for the duration of the conflict. These sutlers, immortalized by Bertolt Brecht in the person of Mother Courage, were content to live off of the war, exacting extortionate prices from underpaid soldiers for inferior goods, without offering anything in return. In the Brecht play Mother Courage and Her Children, Mother Courage refuses to sell schnapps on credit lest her debtor not return from the battlefield, and even goes so far as to refuse to give up some of her material to make bandages. In 1782, the state of sutlering in the West Barns camp was so bad that the Duke of Buccleuch gave orders for the hut of one Agnes Graham to be demolished in view of the fact that "she had suffered soldiers to run into debt for drink, more than their daily substance could pay".2

Until the turn of this century, the provision of essential requirements, refreshments and other canteen supplies to combatant troops, was left to the commanding officer; and indeed, to their credit, those officers with personal financial resources did what they could for their troops. However, in more modern times, this paternal instinct seemed to have evaporated as more officers have been drawn increasingly from the middle classes. The "new type" of officer did not share the feeling of social responsibility which had been inbred in the old "officer and a gentleman" type. Furthermore, the new breed did not have the financial resources which were at the disposal of the noblemen and gentlemen who traditionally made officership their career and had run the British army for time immemorial.

\section{The South African Garrison Institutes}

The ordinary soldier suffered as a result of this democratization of the officer corps. Few of the new officers recognized their social responsibility and even fewer had the finances to see to the needs of their troops. Government contributions remained spasmodic and dependent upon public opinion being occasionally drawn to the appalling conditions in which the men served. Field Marshal the Lord Roberts, British Commander-in-Chief in South Africa during the Anglo-Boer War (1899-1902), realized this problem. He established the South African Garrison Institutes $(\mathrm{SAGI})^{3}$ in an attempt to provide his whole army in South Africa with canteen facilities, offering goods and services at reasonable prices. This proved to be the death blow to sutlering in South Africa.

The name of the organization is misleading. The SAGI was not a South African institute, but a semi-military British institution appointed to supply the Imperial troops in South Africa with refreshments and comforts. At the time South Africa did not exist as a political entity.

The new undertaking met with success and soon permanent SAGI branches were being established in the Cape, Natal and the Transvaal. This prosperity is clearly reflected in the ostentatious stone and brick building built in 
1902 at Roberts Heights at a cost of $£ 26000$, a sum derived from the profits of the field canteens. ${ }^{4}$

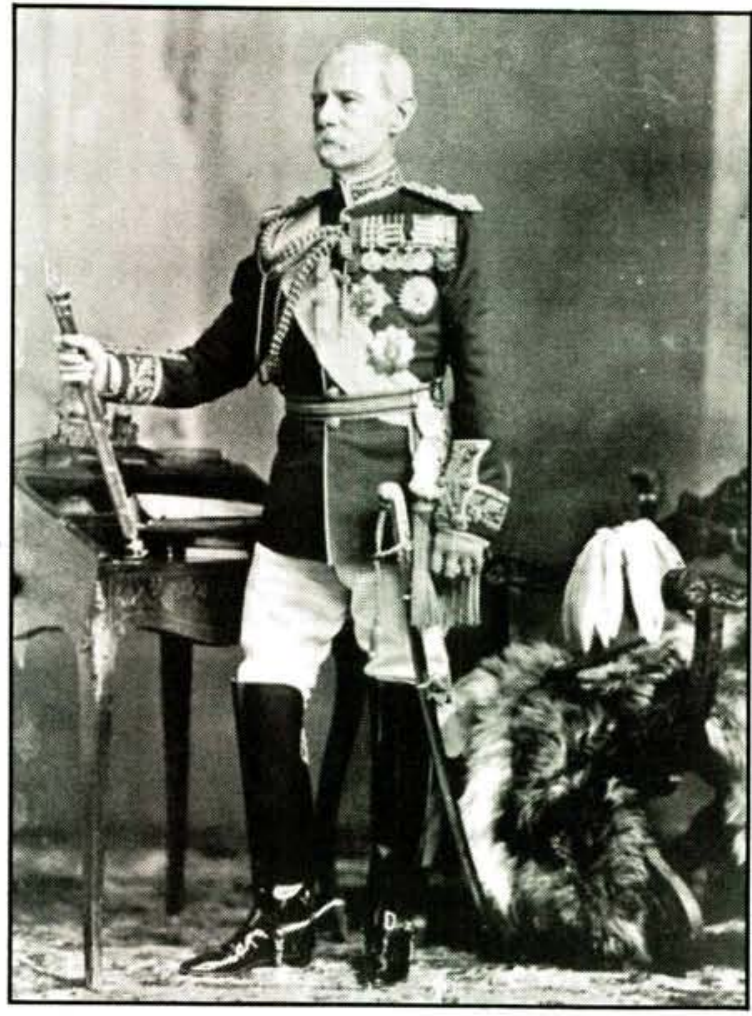

Lord Roberts, with the founding of the SAGI, was the first British Commander-in-Chief to provide his whole army in South Africa with uniform canteen facllities. The present SADFI Is the legal successor of this organization.

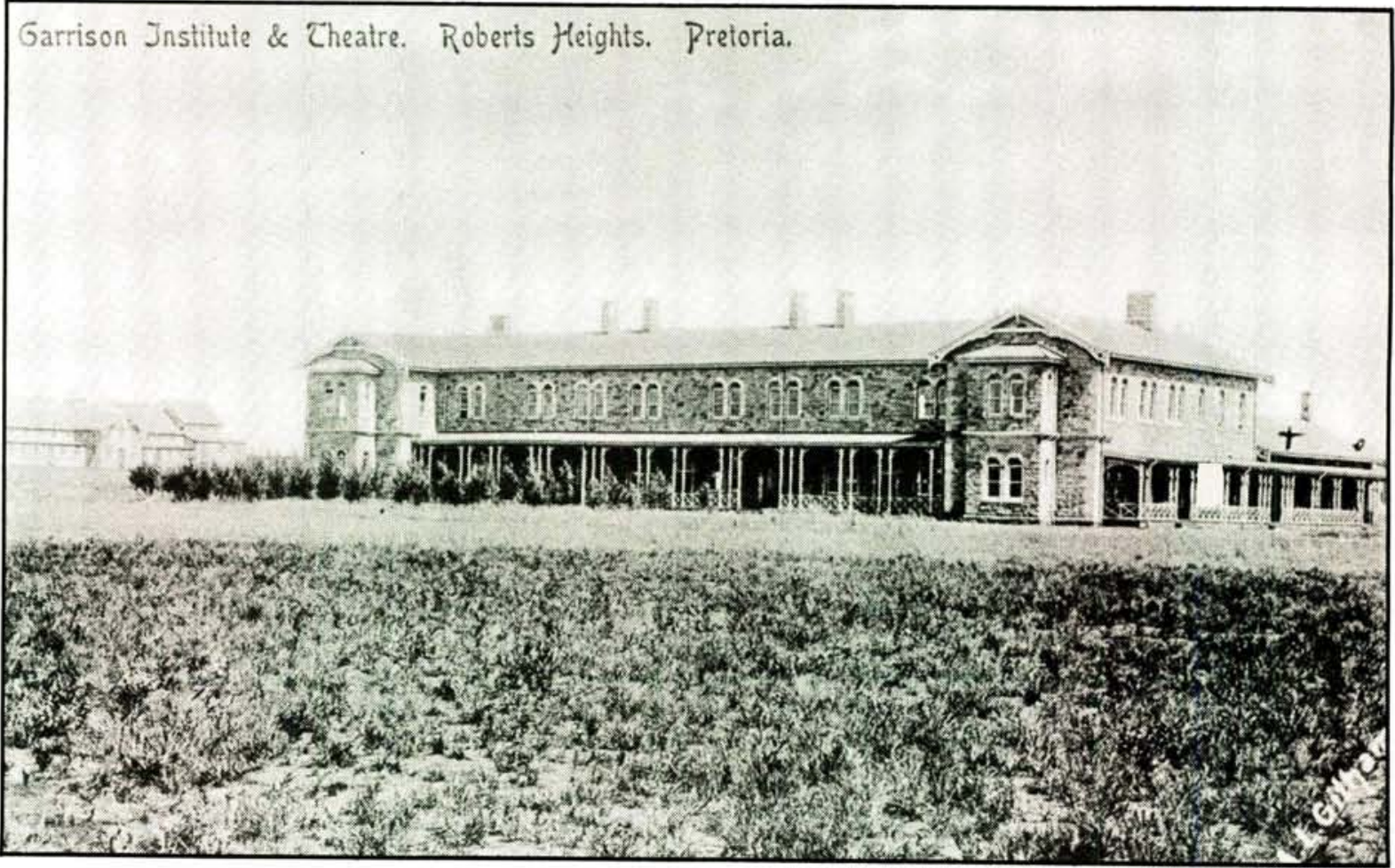

KItchener's Folly, which currently houses SA Army College, was bullt in 1902 from profits generated by the SAGI. Untll 1914, this bullding housed a SAGI shop, the Garrison Church and a Club House for imperial officers. The Union Defence Force bought the bullding from the British in 1920. 
acquired the use of an established and highlyreputed canteen system, so obviating the experience of sutlers before building up her own institute. Hence, the Union Government obtained the use of a British organization for the supply of canteen facilities to the South African troops participating in the invasion of German South West Africa, in exchange for her willingness to actively defend Imperial interests. ${ }^{8}$

When the Union Quartermaster General, Lt-Col M.C. Rowland, asked the Directors of the SAGI to open branches of the Institute for the use of the Union Defence Force, the SAGI undertook to charge reasonable prices, and to hand over any profit to the Union Minister of Defence. The Department of Defence, on the other hand, was to provide the SAGI with "all reasonable facilities" and where necessary furnish military protection for their stores and provide guards when circumstances so required. ${ }^{9}$

However, it was not long before the spirit of goodwill which had been tantamount to the agreement reached on 26 September 1914 , had evaporated. The vagueness of the agreement and the apparent unwillingness of the Union Government to quell rumours of corruption in the SAGI, led General Thompson in July 1915, to say in a letter to General Smuts that :

"...the Directors (of the SAGI) have many times regretted that they ever volunteered their services ... (however, they) are prepared to continue their work, but in this event they ask for more support than has been received sometimes in the past". ${ }^{10}$

In a letter dated 1 April 1915, the British authorities delivered their ultimatum. The Board of Directors called for a "complete investigation" to clear the good name of the South African Garrison Institutes, which, "has held an honourable position in this country for many years and it is not for the present Trustees here to allow it to be constantly and publicly defamed any longer" and unless an enquiry was granted "the only possible course will be for (the Directors) to withdraw the South African Garrison Institutes from German South West Africa altogether"."

Complying with the wishes of the Board of Directors, Lt-Col Rowland constituted a committee consisting of Mr T.Sleith (the general manager of the SAGI) and a representative of the Department of Defence, to inspect the branches of the Institute in South West Africa and deliver a report to the Directors. Despite truth in some of the disparagement, the investigating committee found most of the criticism to be rooted in misunderstanding with regard to the fixing of prices in SAGI shops; the policy regarding the generation of profit; and the details of the concessiuns allowed to the SAGI by the Union Government. In fact, the committee found SAGI prices to compare most favourably with ruling prices in Cape Town (figure 1). However, despite the findings of the investigation and the subsequent steps taken by the Union authorities to improve the image of the SAGI, South African relations with the British directors remained cold.

\section{Union Defence Force Institute}

As a result of the soured relations between Pretoria and The Castle and the fact that since the last quarter of 1914, the SAGI had devoted most of its attention to the service of the Union Government, the Union Defence Force (in agreement with the British authorities at The Castle) assumed control of the branches of the Institute operating in South West Africa with effect from 1 January 1916, and in the Union with effect from 1 May 1916. ${ }^{12}$

The management and control of the operation passed from the Imperial authorities at The Castle to the Union Defence Force, on condition that the Institutes would revert to British control should the War Office decide to maintain a sizeable garrison in South Africa after the end of hostilities. The contradictory name of the South African Garrison Institutes was finally discarded, at the insistence of the British, for that of the Union Defence Force Institute (UDFI).

The Institute was in an established financial position when the Union Defence Force assumed control. The canteens serving the UDF had realized a nett profit of over $£ 15000$ for the period ended 30 April 1915, and a further £40 148 for the period May to October 1915. Profits would have been even larger had it not been for the looting which had taken place at Lüderitzbucht and the fire in a canteen at Upington. However, in January 1916, the month of the Union takeover of the South West canteens, the Institute was strong enough to make a contribution of $£ 30000$ to the GovernorGeneral's Fund. ${ }^{13}$

The turnover of any one branch of the UDFI was, of course, totally dependant on the number of troops stationed in its vicinity. Fewer troops at the various camps in the Union and the withdrawal of the greater portion of the South African Mounted Riflemen from the South West African Protectorate, resulted in a general shrinkage of business between 30 September 1917 and 31 March 1918 (figure 2). Civilians, in an attempt to inhibit extortion, were permitted to trade with the Institute in South West Africa, and therefore these branches had a larger turnover than their counterparts in the Union (figure 2). This period was also characterized by rising costs, which in turn naturally decreased profits even further. ${ }^{14}$ However, this phenomenon was 


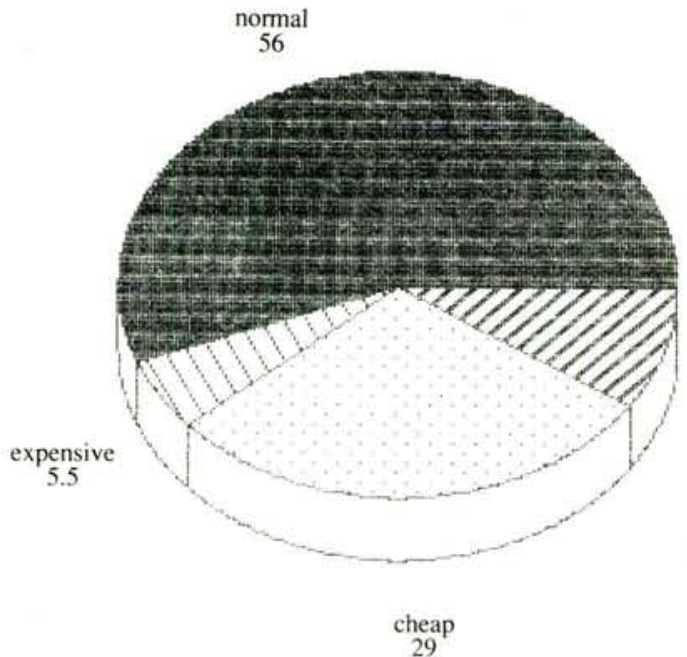

29

\section{very cheap
9.5}

Figure 1: SAGl prices compared to contemp rary prices in Cape Town, reflected as percen ages, 1915. (Source - I.J.van der Waag: A His tory of the South African Defence Force Inst tute, 1914-1989 (Pretoria, 1989), p.5).

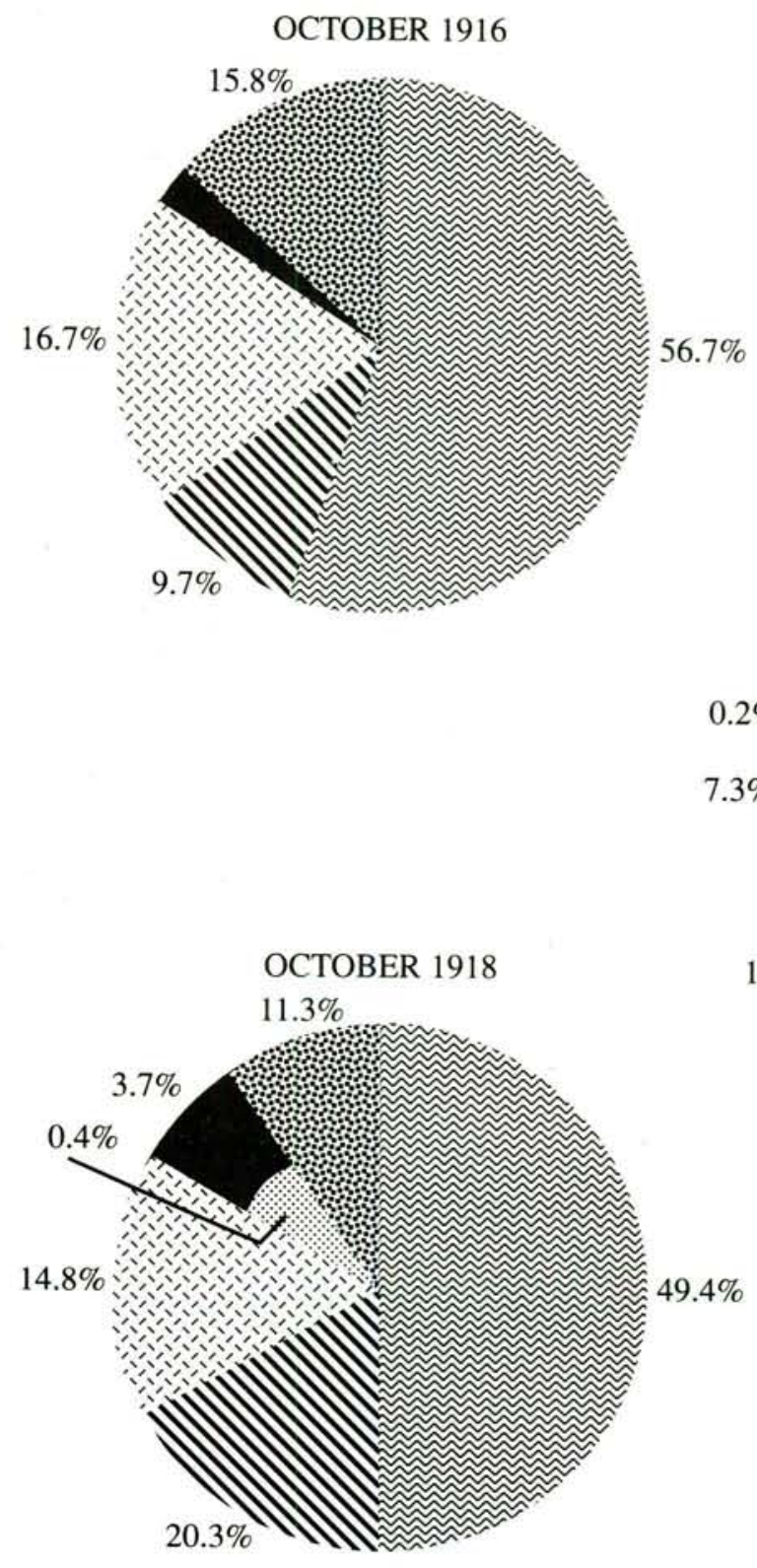

䒕 CAPE PENINSULA

INW PRETORIA

SOUTH WEST AFRIC

DURBAN

\% POTCHEFSTROOM

KIMBERLEY

$56.7 \%$

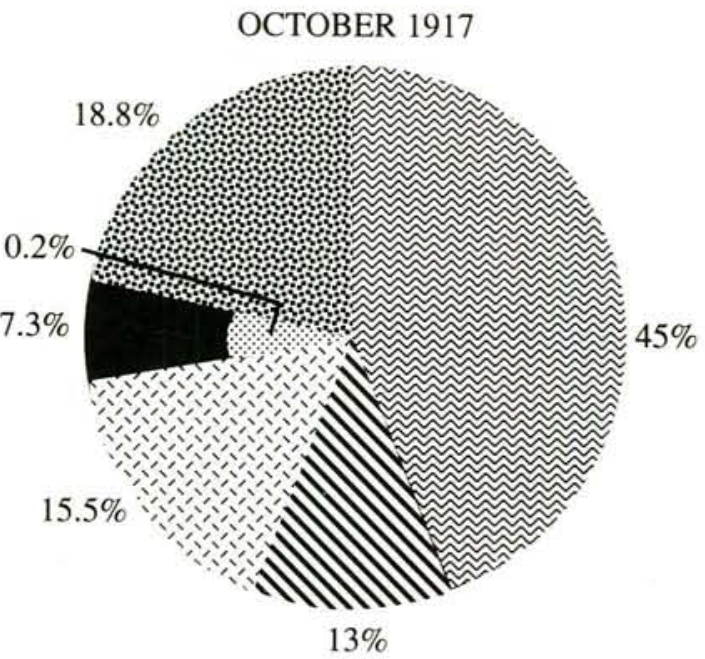

Figure 2: Turnover of the UDFI according to area, in October of 1916, 1917 and 1918. 
not so much one of failure, as a small net profit was embodied in the aim of the Institute, which was to supply goods at the lowest possible price and not make large profits.

As a result of mounting public criticism and post-war rationalization, the UDFI closed down its canteens in South West Africa on 1 September 1920. However, the absence of the South West canteens generated doubts regarding the continued existence of the low-turnover branches of the UDFI in the Union. Their small trade barely covered the overheads and the directors did not want to increase prices as this would defeat the whole object of the Institute. As a result, the shops in the Union were liquidated on 28 February 1922, with the exception of a small number of canteens at Pretoria and Cape Town, which were reconstituted to form, with effect from that date, the Pretoria Garrison Institute (PGI) and the Cape Peninsula Garrison Institute (CPGI), respectively. Both institutes, each with its own general manager, functioned under the supervision of their Management Committees and the UDFI Board of Control. taken their discharge at the end of the First World War neglected to settle their accounts with the UDFI and as a result, enormous amounts had to be written off as bad debts. Both the PGI and CPGI, by force of circumstance, repeatedly turned to the UDFI Trust Fund for further financial assistance. The PGI even began to sell beyond the customers' levels of credit so as to boost declining sales figures.

From the middle thirties it had become increasingly apparent that the Garrison Institutes were not functioning efficiently. In December 1939, at the request of the Board of Control, a Board of Inquiry was appointed by the Secretary for Defence to investigate the activities of the UDFI, and in particular the PGI. The investigators reported an absolute lack of supervision on the part of the Board of Control, which had also become the source of numerous irregularities. By October 1941, the Board of Control's apathy to the Commission's recommendations was indisputable. Few of the recommendations were acted upon and on the more important issues,

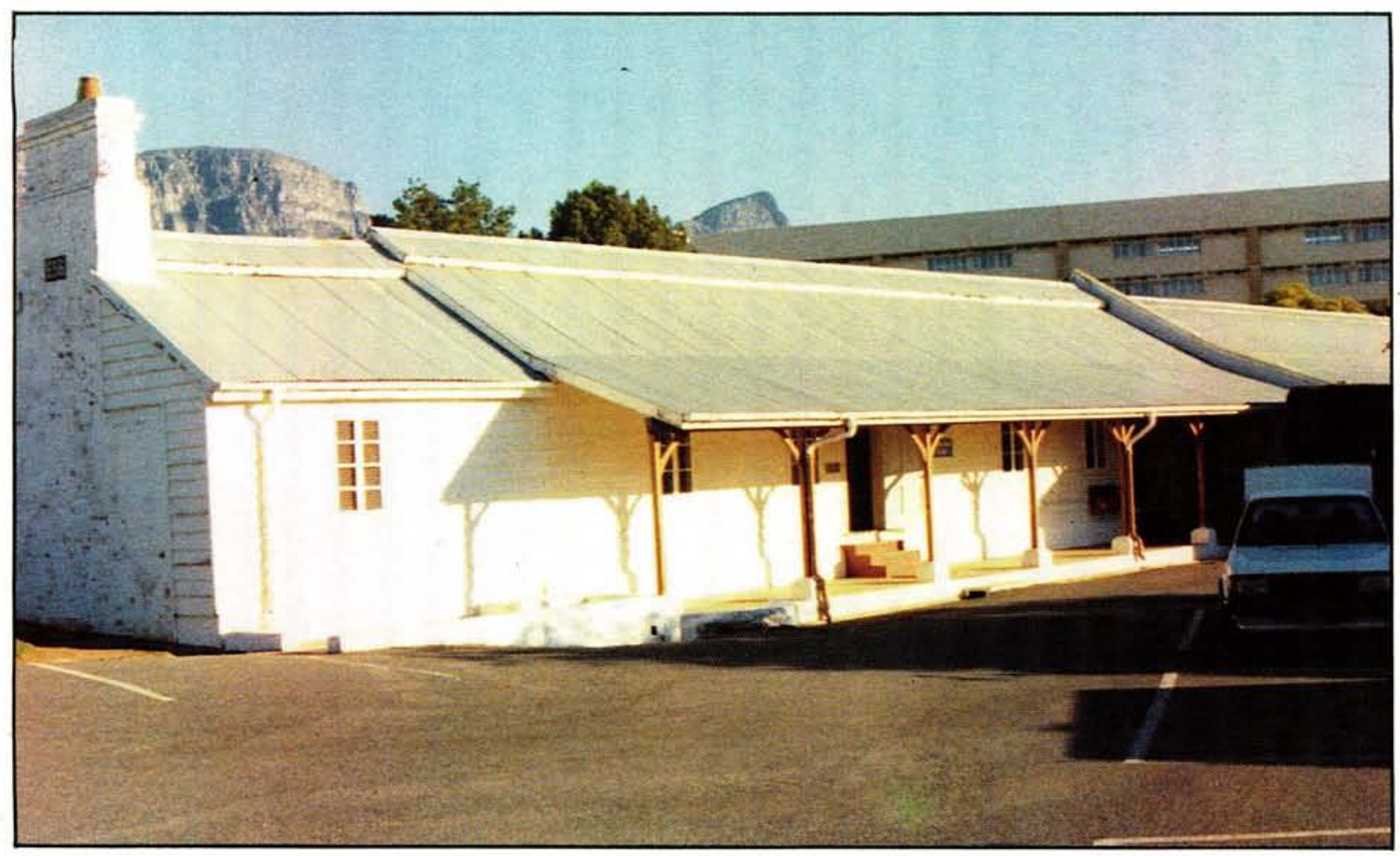

This wood and iron bungalow housed the CPGI shop in Wynberg from 1921 until 1961. It was taken over from the Imperial authorities in that year and might well have housed the SAGI canteen from before the First World War.

The UDFI (PGI and CPGI) did not, share in the rapid growth experienced by the Union Defence Force in the 1930's. As far as the Institutes were concerned, this period was eclipsed by a worstening financial position. The Garrison Institutes had no fixed nominal capital. Initial trading funds had been obtained in 1921 from an interest free loan from the UDFI Trust Fund, which had been established from the funds acquired on the liquidation of the canteens in 1920 and 1921. Many of the troops who had no action appears to have taken place at all. In 1944 , the PGI was on the verge of bankruptcy. No provision had been made for the redemption of the UDFI Trust Fund loans, most of which had been dissipated on excessive rebates to customers instead of being used to secure the financial stability of the Institute. In July 1945, at variance with the dilatory behaviour of the Board of Control and contrary to the power vested in him in terms of the UDFI constitution, the Secretary for Defence felt forced to act. A 
direct confrontation with the Chief of the General Staff, chairman of the Board of Control, was averted in the eleventh hour and a temporary improvement in the management of the Institutes was effected.

\section{Second World War}

As a result of the bad reputation the Garrison Institutes had built up over the past decade, a new organization, the Union Defence Force Institutes (V), was established on 1 November 1940 , to supply members of the UDF with canteen facilities during the Second World War. All personnel were provided by the YMCA and Toc $\mathrm{H}$ welfare organizations. With effect from 27 October 1941, the UDFI(V) was fully militarized and placed under the administrative and disciplinary control of the officer commanding "Q" Services Corps. It was this outfit and not the PGI and CPGI, which misleadingly formed another organization also called the UDFI, that went on to serve South African and in many cases Allied units in no less than five theatres of war between 1939 and 1945. The UDFI(V) was disbanded in 1947 in the wake of post-war rationalization. ${ }^{16}$

\section{Post-War Reorganization 1946-1952}

Between 1946 and 1952, the Garrison Institutes underwent drastic reorganization in an attempt to redeem the financial predicament in which they found themselves, and to improve their public images. In 1949, the institutes received a single general manager for the whole of the UDFI, and in the same year the inconsequential Management Committees of the PGI and CPGI were abolished, making the general manager of the UDFI directly responsi- ble to the Board of Control for the proper management of both institutes. The reorganization was completed when all the Garrison Institutes were amalgamated in 1952, to re-form the Union Defence Force Institute.

Despite this reorganization, matters did not improve in the long term. The question of credit, which had always been something of a motley issue, remained unaddressed. Officers and other ranks, struggling to exist on appallingly low pay, were able to purchase from the institutes on tick and as a result, fell into enormous debt. Hundreds became victims of a credit system from which they could not escape. The general manager was well aware that uncontrolled credit was his life-line, and was unwilling to take steps which would negatively influence his turnover.

However, abuse of credit facilities was not the only complaint directed against the UDFI. Prices were inflated and no standard price was set for any particular item in any one of the branches. The institute did not stock reasonable quantities of goods, and, as a result, goods in short supply were withheld from other ranks and were sold only to officers. On the whole, customers perceived the staff as incompetent and "on average the service (was) slovenly, grudging and often downright rude". ${ }^{17}$ Those members of the UDF that could afford to take their custom elsewhere did so. The general opinion was that the Institute no longer justified its existence, as it no longer fulfilled the function of supplying the soldier cheaply and expeditiously. In short, the UDFI had degenerated into a persona not incomparable to an Agnes Graham or a Mother Courage.

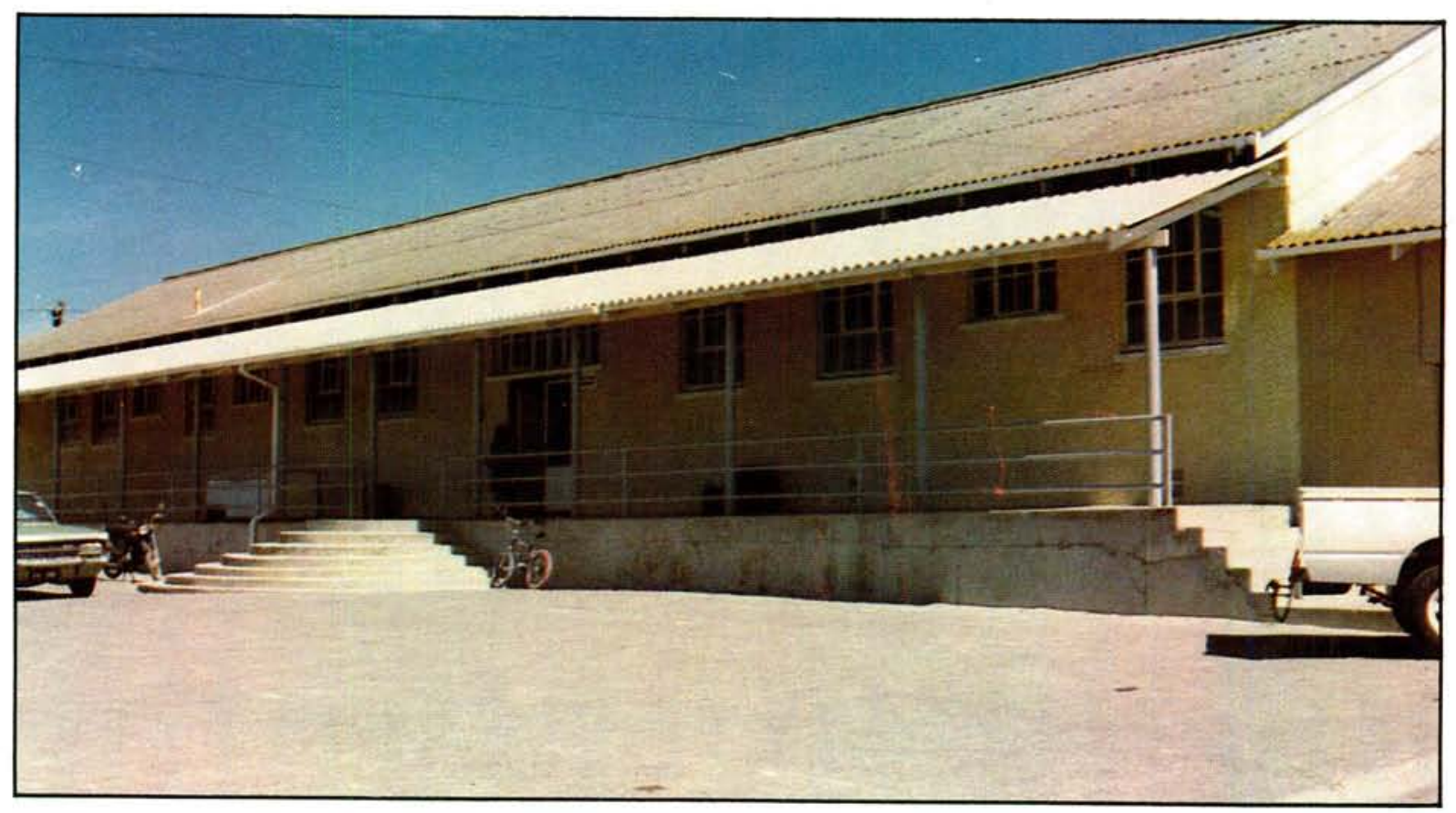

This building was occupied by the CPGI and served as the main shop on Robben Island from 1 February 1949. (With permission of the Department of Correctional Services) 


\section{Board of Enquiry}

Continual complaints were passed from unit to formation and higher headquarters, until finally in September 1952, the Cabinet decided to appoint a Board of Inquiry to investigate the financial prospects of the UDFI and make any recommendations deemed necessary to ensure the achievement of the purpose for which the Institute was established. ${ }^{18}$

The Board of Inquiry studied in detail the financial position of the UDFI from 1940 through to 1953, and in their report, they found that the Institute had not been effectively managed since its inception. The investigators had no doubt that the general manager had to be fired and that the control of the UDFI had to be taken away from the Board of Control which had proven itself totally incapable of proper supervision. ${ }^{19}$

To the best knowledge of Brigadier L.B. Hop-

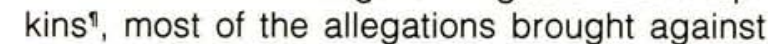
the general manager were gross exaggerations. ${ }^{20}$ The powers that be were of the same opinion, and the general manager managed to survive until the next inquiry seven years later. The Board of Control was neither abolished nor reconstituted in 1953, and only succumbed with the general manager in February 1961.

\section{Decline 1953-1961}

The Board of Inquiry found that the convenience of a nearby shop for married members of the UDF living in military bases where necessities could not be obtained at reasonable prices, to be the only justification for the continued existence of the Institute. The stop order credit system was condemned as a social evil and the board recommended that it be done away with in totality. ${ }^{21}$ The Minister of Defence, Adv F.C. Erasmus, immediately implemented this recommendationt. Existing debt was collected over a period of time in relatively small amounts so as to prevent members of the UDF from falling into further financial difficulty as a result of the change over. ${ }^{22}$

As predicted, the financial strength of the UDFI drastically deteriorated. The abolition of the stop order credit system caused an immediate drop in turnover (table 1). The general manager's life-line had been cut. From 1955, the Institute could no longer ensure profitable trade. On 31 August 1954, liquid assets exceeded sundry creditors by only £96 441 ; by 25 February 1956, this figure stood at $£ 70506 .{ }^{23} \mathrm{~A}$ short lived improvement took place in 1959, but thereafter the negative trend became even more evident. The Institute's nett value dropped from £42 511 in 1955 to £15 075 in $1961 .{ }^{24}$

\begin{tabular}{|lr|}
\hline PERIOD & TURNOVER \\
\hline Year ended 31 Aug 1954 & $£ 524028$ \\
Year ended 27 Aug 1955 & $£ 436940$ \\
6 months ended 25 Feb 1956 & $£ 199135$ \\
\hline
\end{tabular}

Table 1 : Turnover of the UDFI, 1 Sep 1953 - 25 Feb 1956. (Source: DC, Box 1500, file DC 11/2 South African Defence Force Institute Trust Fund).

In the meantime, in terms of the Defence Act Amendment Act (Act No 44 of 1957), the Union Defence Force was renamed South African Defence Force. This inturn required the UDFI to change its designation, and on 1 December 1957, the organization's name changed to South African Defence Force Institute (SADFI). The headquarters remained in Pretoria, where most of the business was conducted, although a majority of the branches were still situated in the Cape Province.

\section{The Road to Militarization 1961-1968}

By 1961, it was clear to all that there was a definite need for drastic and immediate steps to rectify the situation and establish a sound financial base for the Institute. Two of the unimplemented recommendations of the 1953 Inquiry were now put into effect. The general manager was dismissed and the Board of Control was reconstituted.

The new Board of Control, wanting a clean start, immediately commissioned a firm of accountants to satisfy the Board as regards:

"the solvency, and the soundness or otherwise of the policies, organizational structure and general conduct of the affairs of the Institute during the past 3 years". 25

In a comprehensive report, probably the first since the establishment of the Institute, the auditors highlighted a number of shortcomings in the general organization of the Institute. They found a complete lack of supervision throughout the organization; poor definition of authority and responsibility; a lack of trading capital; and the absence of a direct link between the management and the Board of Control. ${ }^{26}$

In reaction, the reconstituted Board appointed a retired officer, Major W.E. Brooks, as the new general manager and gave him a seat on the Board of Control. An area manager was appointed in the Cape, who now assumed responsibility for the far-away and much neglected branches at Port Elizabeth and Grahamstown.

For five years after 1961, the new management tussled with the slow process of getting rid of the rot and trying to establish a firmer financial 
footing. Incompetent staff were dismissed and an aggressive advertising campaign was launched in an attempt to persuade ex-customers to return their business to the SADFI. New lines of stock, special offers and cash discounts were introduced. Credit ceilings were approximately R20 000 per year. ${ }^{27}$ However, the new management's greatest accomplishment was achieved in 1967, when cash sales had increased to such an extent that they exceeded credit sales for the first time in both provinces (table 2).

\begin{tabular}{|l|ccc|ccc|}
\hline & \multicolumn{3}{|c|}{ CAPE SALES (RAND) } & \multicolumn{2}{c|}{ TRANSVAAL SALES (RAND) } \\
\hline $\begin{array}{l}\text { PERIOD } \\
\text { ENDED }\end{array}$ & CASH & CREDIT & TOTAL & CASH & CREDIT & TOTAL \\
\hline \multirow{2}{*}{ 20 Feb 65 } & 58689 & 118915 & 177604 & 176248 & 359271 & 535519 \\
& $(33 \%)$ & $(67 \%)$ & $(100 \%)$ & $(32,9 \%)$ & $(67,1 \%)$ & $(100 \%)$ \\
21 Aug 65 & 56369 & 106740 & 163109 & 182861 & 261245 & 444106 \\
& $(34,6 \%)$ & $(65,4 \%)$ & $(100 \%)$ & $(41,2 \%)$ & $(58,8 \%)$ & $(100 \%)$ \\
19 Feb 66 & 65262 & 113141 & 178404 & 230290 & 222478 & 452768 \\
& $(36,6 \%)$ & $(63,4 \%)$ & $(100 \%)$ & $(50,9 \%)$ & $(49,1 \%)$ & $(100 \%)$ \\
& 85142 & 116526 & 201669 & 280295 & 273400 & 553695 \\
18 Feb 67 & $(42,2 \%)$ & $(57,8 \%)$ & $(100 \%)$ & $(50,6 \%)$ & $(49,4 \%)$ & $(100 \%)$ \\
& 115276 & 127536 & 242812 & 300644 & 275759 & 576403 \\
& $(47,5 \%)$ & $(52,5 \%)$ & $(100 \%)$ & $(52,2 \%)$ & $(47,8 \%)$ & $(100 \%)$ \\
19 Aug 67 66 & 125658 & 93234 & 218892 & 262790 & 245057 & 507847 \\
& $(57,4 \%)$ & $(42,6 \%)$ & $(100 \%)$ & $(51,7 \%)$ & $(48,3 \%)$ & $(100 \%)$ \\
& 138118 & 77108 & 215226 & Not & Not & Not \\
& $(64,2 \%)$ & $(35,8 \%)$ & $(100 \%)$ & known & known & known \\
\hline
\end{tabular}

clamped down. The Institute began to reach out to the defence force, and slowly, suspicions evaporating, the defence force returned their support to the Institute.

By 1965, financial improvement was evident. The Transvaal adverse balance (R72 064 in February 1961) was reduced to R48 895; while accumulated profits in the Cape (R38 754 in February 1961) were built up to R48 364 . Monthly turnover was maintained in both areas, averaging R79 100 in the Transvaal and R26 300 in the Cape, while the percentage of gross profit on turnover at cost continued to improve as a result of closer Board control and improved management:

\begin{tabular}{|lcl|}
\hline & TRANSVAAL & CAPE \\
\hline Feb 1961 & $13,9 \%$ & $11,1 \%$ \\
Aug 1964 & $22,6 \%$ & $19,5 \%$ \\
\hline
\end{tabular}

(Source: SADFI, file SAWI/FIN/2 Auditors reports and correspondence - Transvaal area).

Although suffering a financial set-back in 1966, the Board of Control continued along its path of reformation. The chaotic debtors' accounts were computerized, the first statements on this system going out in August 1966, so saving
Table 2: Cash and credit sales reflected as percentages of total turnover, according to province, August 1964 - February 1968. (Source: Archive of the Chief of Defence Staff, Box 764, file HVS/417/2/1 Vol 1 SAWI (Finansiële State)).

This remarkable change was largely due to the new lines stocked by the new management, a clamp down on credit ceilings, the introduction of special offers and cash discounts and a very successful advertising campaign. ${ }^{28}$

However, despite this breath of fresh air, the SADFI remained burdened with the largest single problem which had been haunting the Institute since 1916. This was the fact that the Institute remained an attempt to run a civilian shopping organization inside the SADF for members of the SADF. The staff had no military background and were more often than not totally out of touch with their military customers. At the same time, the members of the Board of Control were soldiers, who, with the exception of Colonel L.B. Hopkins (chairman 1966-1968), had no financial background; and it was these soldiers who had to supervise the general and financial functioning of the enterprise! The whole structure had to be taken out of the purely business arena and adapted to suit the envi- 
Despite the price reductions to clear stocks, write-offs to clear the books of the last of the remaining bad debts, and the fact that the Institute only came under the effective control of the new management from 1 June 1968, the trading accounts for the period 1 March 1968 to 31 August 1968 reflected for the first time in two years a small profit (approximately R6 000) in the Transvaal. ${ }^{33}$ By 1971, turnover exceeded R4 million and an adverse balance of R171 800 (in 1968) was converted into a substantial excess of assets. A large overdraft was liquidated and loans from the Army. Air Force and Navy funds were paid off in full.

The results proved beyond all doubt the immense value SADFI could have for members of the SADF, and completely justified the foresight and confidence of the Supreme Command in keeping the Institute alive in the 1960s. ${ }^{34}$

\section{Consolidation 1971-1976}

Following this amazing rescue, Brig Hopkins set about the arduous task of building up the SAD$\mathrm{FI}$ and consolidating its growth potential so as to enable the Institute to meet the increasing demands of the SADF, which was now embroiled in an unconventional war on the South West Africa/Angolan border.

Despite a major set-back in 1972, when the SADFI Trust Fund demanded repayment of certain loans, ${ }^{35}$ the Institute continued to expand at a rate that was beyond all expectation. By June 1973, the Institute had been rehabilitated to such an extent that the Director General, General Administration could report to the Defence Staff Council that:

"There is no way in which a meaningful comparison can be made between the disreputable and bankrupt SADFI of early 1968 and the new SADFI', ${ }^{36}$

The remarkable consistency of SADFI's growth may be measured by the fact that the percentage of growth for the years preceding 1974 were as follows:

\begin{tabular}{|cc|}
\hline YEAR & $\begin{array}{c}\text { PERCENTAGE } \\
\text { OF } \\
\text { GROWTH }\end{array}$ \\
\hline $1970 / 1971$ & $26 \%$ \\
$1971 / 1972$ & $26 \%$ \\
$1972 / 1973$ & $19 \%$ \\
$1973 / 1974$ & $20 \%$ \\
\hline
\end{tabular}

By 1974, the SADFI had become a highly successful and stable enterprise with surplus assets (excluding buildings and major equipment) exceeding R650 000. This surplus was invested in stock-on-hand which had an average turnover of R500 000 per month. However, this was only just enough to finance advantageous quantity buying deals, but far too short of the amount needed to finance the long term development programmes essential for future growth. Trading profits since 1968 had been largely absorbed by the reversal of the 1968 adverse balance of $\mathrm{R} 172 \mathrm{000}$; the reduction of the Trust Fund loans; the full repayment of the loans to the Army, Air Force and Navy funds in 1971; and the financing of the Institute's growth of about $475 \%$ between 1968 and 1974 . The financial problem was further compounded by the late payment of SADFI's debtors. By 1974, development was slowing down in view of this acute shortage of trading capital. As a result, an amount of R70 000 held in the Development Reserve and painstakingly accumulated from profits built up since 1968, had to be transferred to the Institute's capital account for use as trading capital. ${ }^{37}$

However, this growth was largely restricted to the Transvaal, with the result that the Institute never really progressed in the Cape. The largest factor underlying this phenomenon was the dispersed nature of the military camps in that province. Although the situation improved to a limited extent with the expansion of the $\mathrm{Da}$ Gama Park branch and later developments at Wynberg, there was no military complex in the Cape comparable to Voortrekkerhoogte. Growth was therefore much more expensive and contained the prospect of a far smaller return. Therefore, it is not surprising that during the 'rescue years' the management concentrated on the Transvaal area.

\section{Growth $1976-1989$}

By the late seventies, the Institute, which had shown tremendous growth during the preceding eight years, was now once again in danger of stagnation. ${ }^{38}$ Supermarkets, which were just getting off the ground when the SADFI militarized in 1968, had become the new competition; and SADFI was not supermarket-orientated. The Institute's buildings were not conducive to modern trading and most of its shops were corner cafes. There was no way the management could compete with the new supermarkets and hypermarkets size-wise. ${ }^{39}$

However, under the business leadership of the new general manager Brig B.D. Slater, and the new controlling authority, R Adm M.A. Bekker $^{f}$, the Institute rose to the occasion. Eminent stagnation was routed with the implementation of two important measures taken to con- 


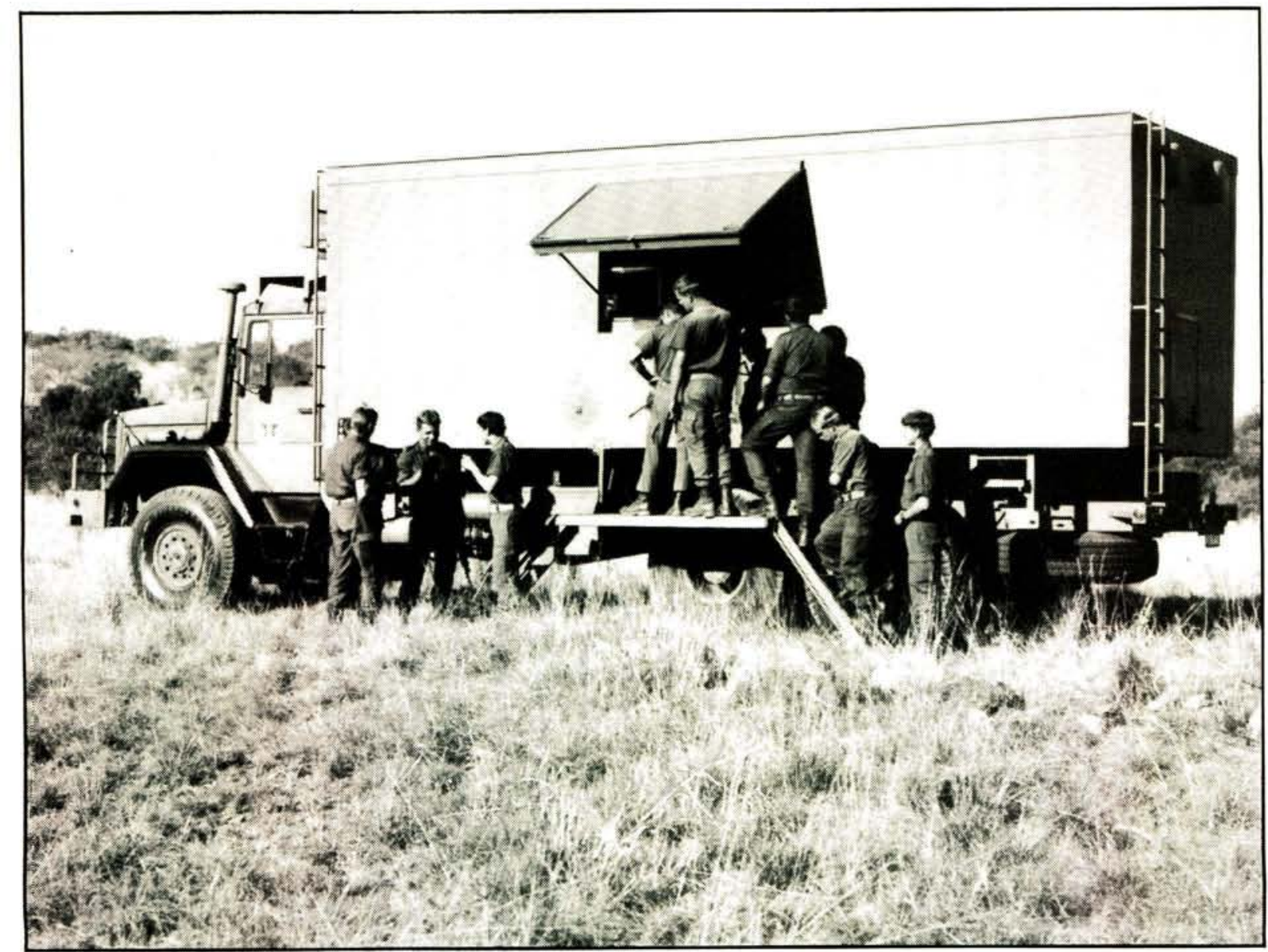

During the early years, the Institute's emphasis was on retail trade. However, after 1976 (Operation Savannah) attention was drawn to the need for an effective operational support service. In conjuction with Armscor, mobile canteens were developed and deployed operationally.
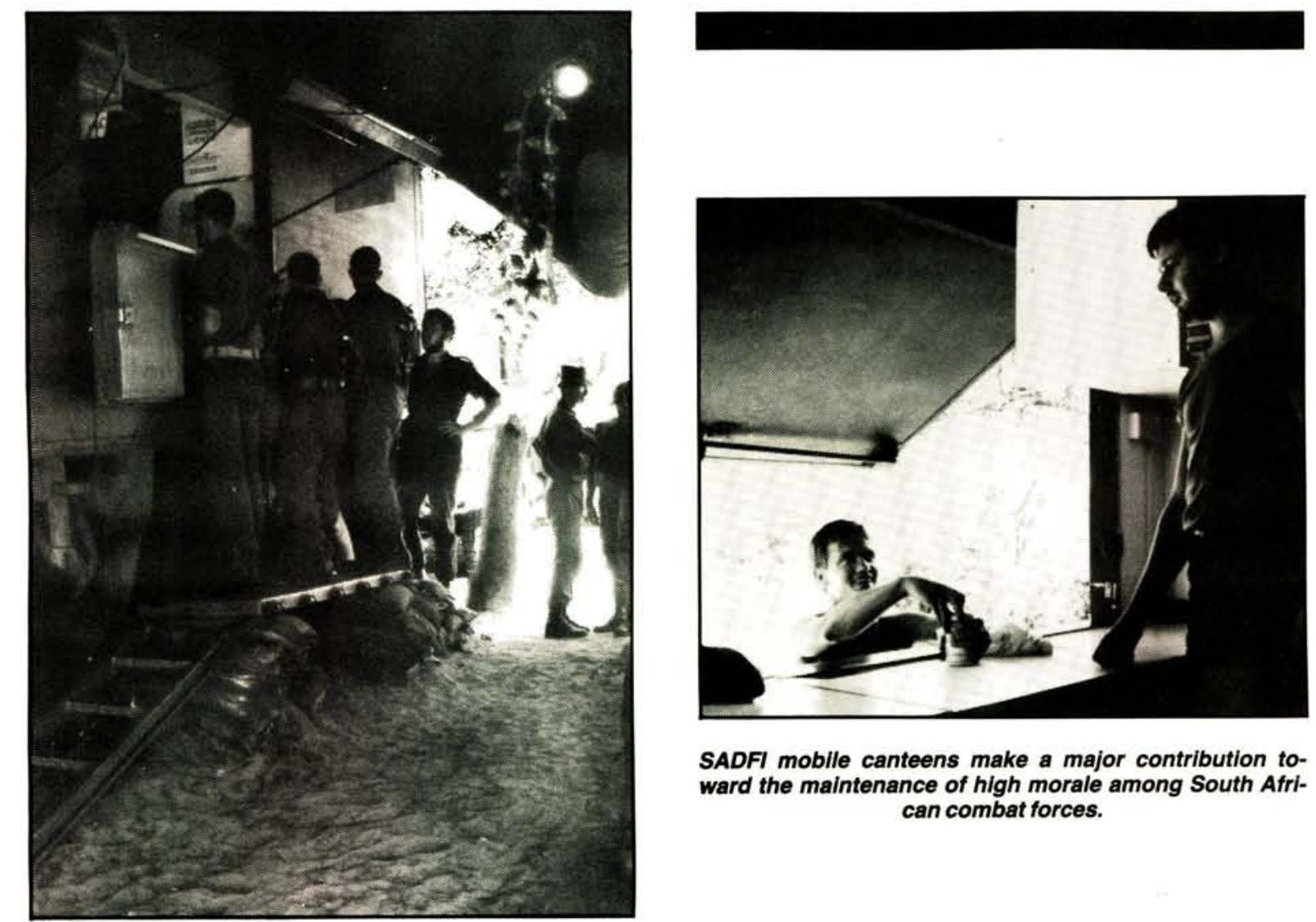

SADFI mobile canteens make a major contribution toward the maintenance of high morale among South African combat forces. 
vert the Institute into a dynamic and profitable organization capable of providing real benefits to servicemen. The first of these measures was the 1978 decision to create a modern shopping complex at Voortrekkerhoogte and the second were the steps taken to make SADFI more competitive price-wise ${ }^{40}$

Within a decade, SADFI had developed from an enterprise that was relatively unpopular within the military community to one which had obtained their respect and confidence. However, despite the drastic improvement in the benefits and facilities offered, some members of the SADF remained critical of their Institute..$^{41}$ SADFI was not adequately market-orientated. This caused a breakdown in communication between Institute and customer. Prices were seen as higher than what they really were, as customers were not aware of the discounts on the various products. The popular perception was that SADFI was still very expensive. ${ }^{42}$ Market research showed that most of the customers did not understand the complicated price structure. They compared the shelf price at SADFI with the shelf price elsewhere, without taking the cash discounts into reckoning. At Col (now Brig) F. Dannhauser's ${ }^{\ddagger}$ suggestion, the discounts were done away with in 1980, and all prices were reduced by an average of $10 \%{ }^{43}$

A survey conducted in 1979, confirmed the notion that the military community were not giving their maximum support to SADFI. Residents of Voortrekkerhoogte spent approximately $64 \%$ of their monthly budget on consumer goods at SADFI, while members of the SADF resident in neighbouring areas, such as Valhalla and Verwoerdburg, where competition existed, tended to support SADFI considerably less. The same survey found that national servicemen and junior ranks tended to support SADFI better a. Geographic problem. Residential patterns reflect that senior ranks, concentrated in the neighbouring suburbs, supported SADFI less than members of lower rank, who were concentrated in and around the officers' clubs, NCOs messes and training camps of Voortrekkerhoogte and hence had a greater opportunity to buy from the Institute. 45

b. Type of market. SADFI tended to cater for the national servicemen, although this is changing in the Voortrekkerhoogte outlets, where greater attention is now given to the monthly purchases of permanent force families. ${ }^{46}$

c. Reputation. The junior ranks were relatively new in the SADF and were therefore only acquainted with the "new" SADFI of the post-militarisation era. They were therefore not aware of the previous bad reputation of the Institute. 47

Over the past decade, SADFI has launched massive advertising campaigns in an effort to reach the military community - the Institute's only source of custom. The more professionally orientated management introduced innovative ideas. Marketing strategy was implemented and SADFI began to set competitive prices. ${ }^{48}$ "New look" shops gradually replaced the obsolete buildings inherited from the old management, services were extended and the number of SADFI outlets increased dramatically between 1976 and 1989 (table 3). Credit was granted under controlled circumstances and enormous sums of money were diverted to provide facilities for the military community, including two kindergartens in Voortrekkerhoogte. ${ }^{49}$

\begin{tabular}{|c|cccc|c|c|}
\hline DATE & TVL & OFS & CAPE & SWA & TOTALS & $\%$ \\
\hline pre 1968 & 4 & - & 6 & - & 10 & 19.6 \\
$1969-1975$ & - & - & 3 & 1 & 4 & 7.8 \\
$1976-1982$ & 8 & - & - & 1 & 9 & 17.7 \\
$1983-1989$ & 12 & - & 3 & 7 & 22 & 43.1 \\
Unknown & 2 & 2 & 2 & - & 6 & 11.8 \\
\hline TOTALS & $\mathbf{2 6}$ & $\mathbf{2}$ & $\mathbf{1 4}$ & $\mathbf{9}$ & $\mathbf{5 1}$ & $\mathbf{1 0 0 . 0}$ \\
$\%$ & $\mathbf{5 1}$ & $\mathbf{3 . 9}$ & $\mathbf{2 7 . 5}$ & $\mathbf{1 7 . 6}$ & $\mathbf{1 0 0}$ & - \\
\hline
\end{tabular}

than senior ranks. ${ }^{44}$ To a lesser or greater extent, this phenomenon can be ascribed to one or more of the following factors:
Table 3: Geographical location and date of opening of all SADFI branches, 19681989. 
$8.9 \%$ in 1988 . Nett profit fared even worse. It decreased from $3.6 \%$ of sales in 1988 , to $2 \%$ of sales in 1989 . This was way below the $7.5 \%$ which was deemed satisfactory. The phenomenon could not only be ascribed to the deteriorating economy, but was a clear indication that the objectives set by the management to improve middle management and reduce shrinkage had not taken effect. It was realized that the changing situation necessitated a new approach to the management of the Institute, and a management consultancy firm was appointed to make an indepth investigation, ${ }^{57}$ the results of which, were to have a profound effect.
In addition to poor economic circumstances, by March 1990, SADFI had closed 8 shops in South West Africa (shortly to be renamed Namibia), in consequence of the withdrawal of the SADF from that territory. These shops had contributed R43,3 million (some $30 \%$ ) of the total turnover. The loss of these outlets induced considerable loss to SADFI. More than five hundred thousand rand in fixed assets, was lost.

Against this background, SADFI performed reasonably well in terms of turnover. The actual decrease of only $6.4 \%$, was above expectation. Sales within South Africa showed a stable growth of $19.5 \%$. This was an extremely

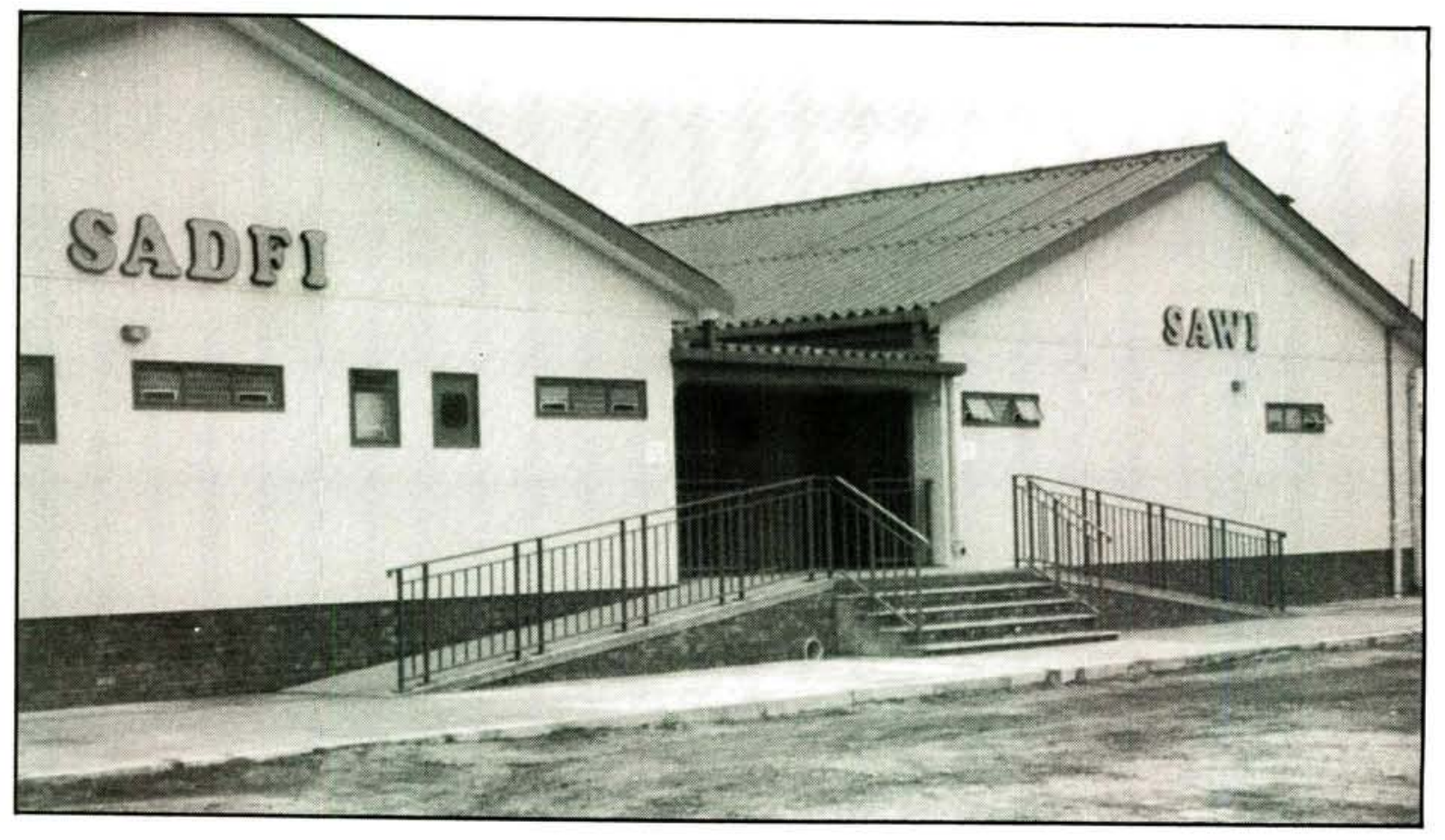

The new shop in Port Ellzabeth was opened in 1986.

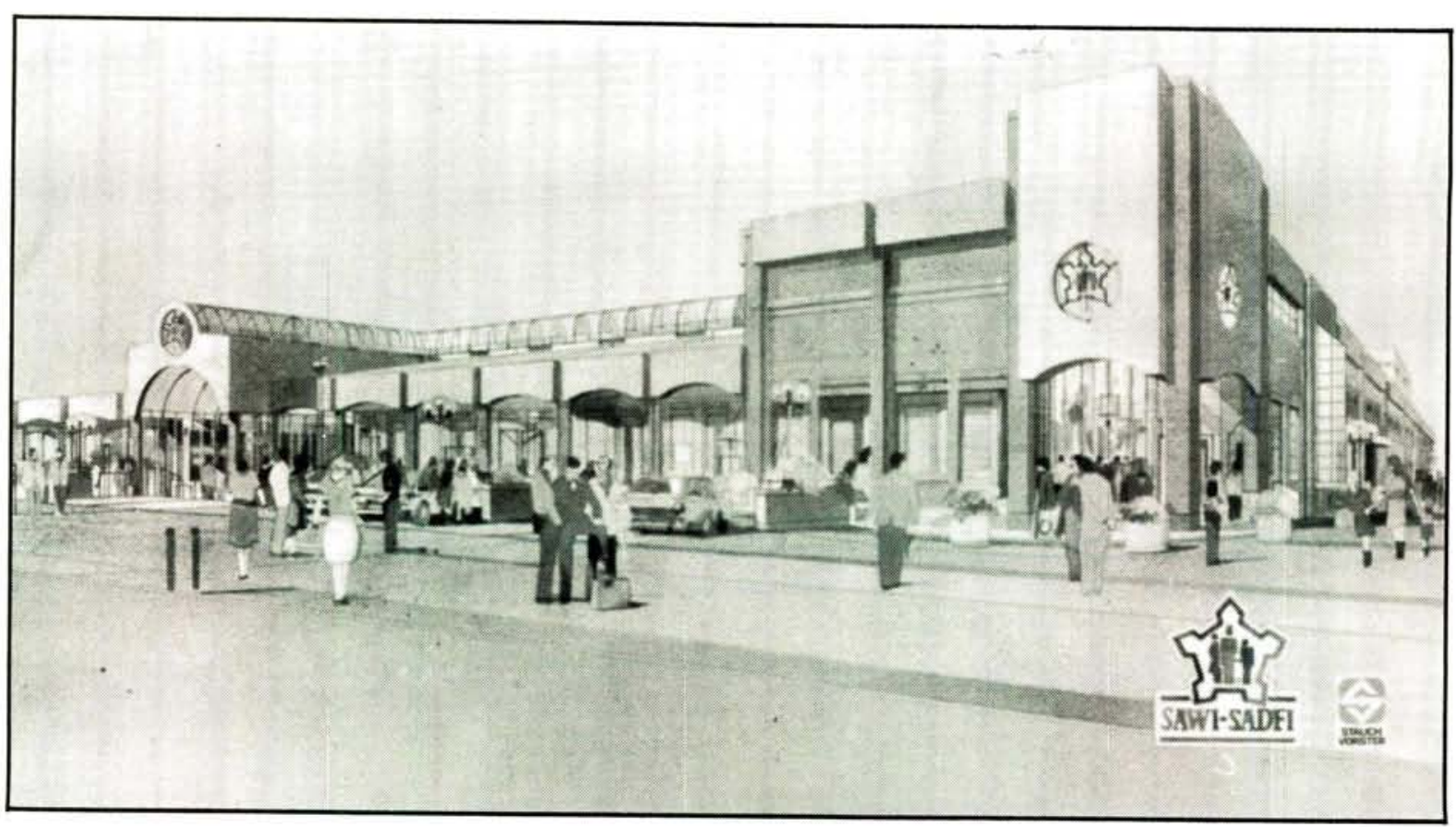

An artist's Impression of the new SADFI shopping complex being erected (1991) in Voortrekkerhoogte. 
respectable figure when one takes into account the loss of turnover following the independence of Namibia. The market leader (Pick 'n Pay) enjoyed a growth in turnover of only $13 \%$. The new outlet at Pomfret, serving the relocated 32 Battalion, did not compensate for the loss of the South West turnover. All eight shops in the territory were closed down, and it would have been naive to believe that one shop opened at Pomfret, would compensate for all eight. However, on the whole, SADFI effectively accommodated the withdrawal following the implementation of Resolution 435.58

\section{New Confidence 1990 -}

Brig Slater, after 22 years of service to the Institute, ${ }^{59}$ retired as general manager on 30 April 1990. He was succeeded by Brig Francois Dannhauser, who had joined SADFI in 1972, at the time when Brig Hopkins was effecting the rehabilitation of the Institute.

However, SADFI is not only entering the 1990's with a new general manager. The Institute is in the process of acquiring a brand new "flag ship". The demolition of the PGI shopping complex erected in 1928 on the south west corner of Andries Pretorius and Van Riebeeck streets, commenced in 1990. The new complex will enable the Institute to expand well into the 21 st century. During the levelling, a number of items were found behind the cornerstone of the old complex. These include an original blue-print plan of the shopping complex, identical to a copy found at Directorate Documentation Service; and a copy of the programme detailing the sequence of events when the foundation stone was laid in 1928. Through the good offices of Director Documentation Service (SADF), this document was restored by the State Archives Service.

The nineties will be an interesting, yet challenging, decade for SADFI. The loss of the South West enterprise (for the second time in the Institute's history) and the post-Botha rationalization of the Defence Force, has demanded certain important adjustments. The most important of these, was the gearing down of the Institute to a shrinking Defence Force, and therefore, a shrinking clientele. The new management has switched SADFI's emphasis away from growth, toward greater effectiveness and profitability. The whole organizational structure of the Institute was rationalized during the tirst six months of 1990 . This streamlining immediately had its effect. Profitability over the the period 1 April 1990 to 30 September 1990, increased by $300 \% .{ }^{60}$ At the same time, management has and will continue to identify new market opportunities, new products and new services, to compensate for any loss in turnover. ${ }^{61}$
The Institute has had to face similar challenges in the past - the closure of the South West canteens in 1920; the rationalization and reorganization following both World Wars; and the uphill battle to get the Institute on a sound financial footing after 1968. On each occasion, to a lesser or greater extent, the Institute managed to adjust to the changing circumstances and there is no reason to believe that SADFI will not be able to do so again.

* Capt I.J. van der Waag SAMS, B.A. Hons. is attached to Directorate Documentation Service (SADF Archives), SADF.

\section{Notes}

$\S$ All of the archival material referred to in the footnotes of this article are in the custody of Directorate Documentation Service (SADF Archives), unless otherwise stated. For a discussion of the archival sources pertinent to the study of the Institute's history, see "Traces of a military trading organization; archives appertaining to the South African Defence Force Institute" in the South African Archives Journal, vol 32 (1990), pp. 54-64.

I Brig L.B. Hopkins was appointed to the Board of Control in February 1961. He became chairman of the Board in 1966, and held this position until his appointment as general manager in 1968 .

† The report was dated 16 October 1953. The minute informing the Chief of the General Staff and the Secretary for Defence of the Ministers' decision was dated 27 October 1953 , ie only eleven days later.

$¥ \quad$ Brig B.D. Slater succeeded Brig L.B. Hopkins as general manager of the SADFI on 1 August 1976.

$f \quad$ R Adm M.A. Bekker succeeded Maj Gen J.J. Steenkamp as Quartermaster General on 1 October 1976.

‡ Col F. Dannhauser became assistant general manager of the SADFI on 1 January 1983, and succeeded Brig B.D. Slater as general manager on 1 May 1990 .

\section{References}

1. Major A.McK.Annand : Henry, 3rd Duke of Buccleuch and the South Fencibles of 1778-1783 (Journal of the Society for Army Historical Research, vol LIII, No 216, 1975), p.193. 
2. Major A.McK.Annand : Henry, 3rd Duke of Buccleuch and the South Fencibles of 1778-1783 (Journal of the Society for Army Historical Research, vol LIII, No 216, 1975), p.193.

3. H.Miller : Service to the Services; The story of Naafi (London, 1971), p.17.

4. Archive of the Secretary for Defence (DC), Box 424, file DC 51761 SAGI building at Roberts Heights. Minute DB 8/2390/Z dd 26 October 1917 from the Secretary for Defence to the Secretary for Finance.

5. R.Dale : The South African Armed Forces and their link with the United Kingdom and the Commonwealth of Nations, 1910-1961 (Militaria, 9/1, 1979), p.2.

6. DC, Box 631, file 7/220/9199 SAGI - copy of correspondence covering agreement on all points. Enc 3 minutes of special meeting of the Directors of the SAGI held on 26 September 1914.

7. DC, Box 631, file 7/220/9199 SAGI - copy of correspondence covering agreement on all points. Enc 2 telegram A.9199/73 dd 26 Sep 1914 from Quartermaster General to Chebec.

8. I.J. van der Waag: A History of the South African Defence Force Institute, 1914-1989 (Pretoria, 1989), p.2.

9. DC, Box 631, file 220/9199 Field canteens established by SAGI - general matters. Minute A.220/9199 dd 15 Nov 1915 from the Quartermaster General to the Director of Signals.

10. DC, Box 631, file 220/9199 Field canteens established by SAGI - general matters. Minute C.R., S.A 0.745 dd 3 July 1915 from General Thompson, GOC SA Military Command, to General Smuts, Minister of Defence.

11. DC, Box 1428 , file $37 / 4 / 12$ SAGI. Minute C.R., S.A SAGI 16231 dd 1 April 1915 from the Deputy Assistant Adjudant General, South Africa to the OC Union Expeditionary Forces.

12. DC, Box 1274, file DCM/1283 Union Defence Force Institute. Report G.M.2535 by T. Sleith on the Balance Sheet and Accounts of the Union Defence Force Institutes ending 30 Sep 1916.

13. DC, Box 631, file 220/9199 Field Canteens established by SAGI - general matter. Letter dd 21 Jan 1915 (sic 1916) from Sleith to Rowland.

14. DC, Box 1274, file DCM/1283 Union Defence Force Institutes. Balance Sheet and Accounts as at $31 \mathrm{Mar}$ 1918.

15. Archive of the Adjudant General (AG 3) 154, Box 346, file $A G(3) 1.54 / 203 / 32$ Recruiting UDFI. Circular AG(3)154/203/32 dd 27 Oct 1941

16. I.J. van der Waag : Serving the Services; a concise history of the SA Defence Force Institute (Paratus, vol 40, no 6, June 1989), p.33.

17. Archive of the Minister of Defence (MVEF), Box 143, file MV150 Pretoriase Garnisoensinstituut. Minute AFS(VTH) C.825/1/0RG dd 6 Mar 1950 from OC AFS VTH to the OC Northern Command.

18. DC, Box 208, Report DC(P)II/9 by Hoek, Wiehahn and Cross, "Enquiries into UDF Institutes", p.l; and MVEF, Box 143, file MV150 Pretoriase Garnisoensinstituut. Enc 2 "Appointment of a Board to Investigate the activities of Garrison Institutes".
19. DC, Box 208, Report DC(P)II/9 by Hoek, Wiehahn and Cross, "Enquiries into UDF Institutes", pp.60-68.

20. Interview with Brig L.B. Hopkins on 13 Mar 1989.

21. DC, Box 208, Report DC(P)II/9 by Hoek, Wiehahn and Cross, "Enquiries into UDF Institutes", p.23.

22. MVEF, Box 143, file MV150 Pretoriase Garnisoensinstituut. Enc 13 minute MV150 dd 27 Oct 1953 from the Minister of Defence to the Chief of the General Staff and the Secretary for Defence; and interview with Brig L.B. Hopkins on 13 Mar 1989.

23. DC, Box 1500, file DC 11/2 Chap 1 South African Defence Force Institute Trust Fund. Enc 19 minute DF 261 dd 28 Sep 1956 from the Accountant, Department of Defence, to the Chairman of the UDFI Trust Fund.

24. Documents in the custody of the general manager (SADFI), "Suid-Afrikaanse Weermaginstitute, ondersoek- Februarie 1961", p.56.

25. SADFI, Appendix A to "Suid-Afrikaanse Weermaginstitute, ondersoek Februarie 1961".

26. SADFI, "Suid-Afrikaanse Weermaginstitute, ondersoek - Februarie 1961", pp.56-57.

27. Archive of the Quartermaster General (QMG) Group 8, Box 102, file KMG/K1/2/8 SA Weermaginstitute - Balansstate. Enc 5 minute SAWI/FIN/I dd 29 Aug 1966 from Col L.B. Hopkins, chairman of the Board of Control, to the Chief of Logistic Services.

28. Interview with Brig L.B. Hopkins on 13 Mar 1989.

29. I.J.van der Waag : A History of the South African Defence Force Institute, 1914-1989, pp 82-84

30. QMG Gp 12, Box 1, file KMG/K1/1/2 SAW Institute Stigting. Enc 94 memorandum dd Nov 1968 re SADFl: Report to 25 Nov 1968.

31. Interview with Brig B.D. Slater on 25 Jul 1989.

32. QMG Gp 12, Box 1, file KMG/K1/1/2 SAW Institute Stigting. Enc 94 memorandum dd Nov 1968 re SADFI: Report to 25 Nov 1968.

33. QMG Gp 12, Box 1, file KMG/K1/1/2 SAW Institute Stigting. Enc 94 memorandum dd Nov 1968 re SADFI: Report to 25 Nov 1968.

34. QMG Gp 10, Box 138, file KMG/KI///I vol 1. SuidAfrikaanse Weermaginstituut - stigting en organisasie. Enc 42 A General Manager's report for the trading period 1 Sep 1970 to 31 Mar 1971 and supporting audited statements of account.

35. QMG Gp 8, Box 102, file KK1/2/6 vol 1. SAWI Bestuur en Kontrole: Trustfonds. Enc 1 minute DF 261/SAWI dd 28 Nov 1972 from the Commandant General to the Quartermaster General.

36. Archive of the Chief of Defence Force Administration (HWA DGAA), Box 81, file DGAA/42/2/1 vol 1. Instituut en Inrigtings SAWI : Beleid. Notes prepared for the Defence Council - SADFI June 1973.

37. I.J.van der Waag : A History of the South African Defence Force Institute, 1914-1989, pp.92-93.

38. Unit History Archive, QMG vol 1. Enc "Geskiedenis van die KMG".

39. Interview with Brig B.D. Slater, on 25 July 1989.

40. Unit History Archive, QMG vol 1. Enc "Geskiedenis van die KMG".

41. F. Dannhauser : " $n$ Ondersoek na die beeld van die Suid-Afrikaanse Weermagsinstituut by sy klante (Unpub MBA thesis, UNISA 1979), p.53. 
42. Interviews with Brig B.D. Slater and Col F. Dannhauser, on 25 July 1989.

43. Interview with V Adm M.A. Bekker, on 20 July 1989.

44. F. Dannhauser : ' $n$ Ondersoek na die beeld van die Suid-Afrikaanse Weermagsinstituut by sy klante (Unpub MBA thesis, UNISA 1979), p.54-55.

45. Interview with V Adm M.A. Bekker, on 20 July 1989.

46. Interview with Lt Gen K.M. Pickersgill, on 5 July 1989.

47. Interview with Brig B.D. Slater, on 25 July 1989.

48. Interview with Col F. Dannhauser, on 25 July 1989.

49. Interview with Brig B.D. Slater, on 25 July 1989.

50. SADFI, file QMG 507/4/1 Bedryf van Inrigtings : SAWI. Enc 8 minute KMG(1)507/4/1 dd 31 Oct 1984 from the Quartermaster General to the Chief of the SA Defence Force.

51. SADFI, file QMG 507/4/1 Bedryf van Inrigtings : SAWI. Enc 7 minute KMG(1)507/4/1/2 dd 22 Oct 1984 from the Director SADFI to the Quartermaster General.
52. SADFI News, Feb 1985, p.I.

53. Reports Archive, Box 200, Report K86/83 : KMG(1)503/1/10(D SAWI) Verslag oor ondersoek na die organisasie van SAWI dd 23 Des 1985, p.l.

54. Interview with V Adm M.A. Bekker, on 20 July 1989.

55. SADFI, file "Notules - SSO Vergaderings". Enc 18 minutes of SSO meeting, 5 May 1986.

56. Interview with Col F. Dannhauser, 25 July 1989.

57. SADFI, minute $Q M G(I) / B / 507 / 4 / 1 / 2$ over CSL/507/4/1/2 dd 16 Feb 1990 from the Chief of Staff Logistics to the Chief of the SA Defence Force.

58. SADFI, minute HSL/D SAWI/507/4/1/2 dd 1 Sep 1990 from the Director SADFI to the Chief of Staff Logistics.

59. 21 Years Service (SADFI News, July 1989), p.l; and A great farewell for Bryan Slater (Paratus, June 1990), p.22.

60. Interview with Brig F. Dannhauser on 14 March 1991.

61. SADFI, minute HSL/D SAWI/507/4/1/2 dd 1 Sep 1990 from the Director SADFI to the Chief of Staff Logistics. 